\title{
Photocatalytic Hydrogen Production in Water-Methanol Mixture over Iron-doped $\mathrm{CaTiO}_{3}$
}

\author{
J. S. Jang, P. H. Borse, ${ }^{\dagger}$ J. S. Lee, K. T. Lim, ${ }^{\dagger}$ O.-S. Jung, ${ }^{\S}$ E. D. Jeong, ${ }^{\#}$ J. S. Bae, ${ }^{\#}$ and H. G. Kim, ${ }^{\#, *}$ \\ Department of Chemical Engineering, Pohang University of Science and Technology, Pohang 790-784, Korea \\ ${ }^{\dagger}$ Centre for Nanomaterials, International Advanced Research Centre for Powder Metallurgy and New Materials \\ (ARC International), Balapur PO, Hyderabad, AP, 500 005, India \\ ${ }^{\ddagger}$ Department of Imaging System Engineering, Pukyong National University, Busan 609-735, Korea \\ ${ }^{\S}$ Department of Chemistry, Pusan National University, Busan 627-706, Korea \\ ${ }^{\#}$ Busan High Tech Center, Korea Basic Science Institute, Busan 609-735, Korea. "E-mail: hhgkim@kbsi.re.kr \\ Received June 30, 2010, Accepted October 22, 2010
}

\begin{abstract}
$\mathrm{CaTi}_{1-\mathrm{x}} \mathrm{Fe}_{\mathrm{x}} \mathrm{O}_{3}(0 \leq \mathrm{x} \leq 0.4)$ solid solution photocatalysts were synthesized by iron doping during the conventional solid state reaction at $1100{ }^{\circ} \mathrm{C}$ for $5 \mathrm{~h}$ and characterized by ultraviolet-visible (UV-vis) absorption spectroscopy, X-ray diffraction, morphological analysis. We found that $\mathrm{CaTi}_{1-x} \mathrm{Fe}_{\mathrm{x}} \mathrm{O}_{3}$ samples not only absorb UV but also the visible light photons. This is because the $\mathrm{Fe}$ substitution at Ti-site in $\mathrm{CaTi}_{1-\mathrm{x}} \mathrm{Fe}_{\mathrm{x}} \mathrm{O}_{3}$ lattice induces the band transition from $\mathrm{Fe} 3 d$ to the $\mathrm{Fe} 3 d+$ Ti3 $d$ hybrid orbital. The photocatalytic activity of $\mathrm{Fe}$ doped $\mathrm{CaTiO}_{3}$ samples for hydrogen production under UV light irradiation decreased with the increase in the Fe concentration. There exists an optimized concentration of iron in $\mathrm{CaTiO}_{3}$, which yields a maximum photocatalytic activity under visible light $(\lambda \geq 420 \mathrm{~nm})$ photons.
\end{abstract}

Key Words: Fe doped $\mathrm{CaTiO}_{3}$, Solid state reaction, Photocatalysis, Visible light, Hydrogen production

\section{Introduction}

Visible light active photocatalyst has ability to convert the solar energy into chemical energy $\left(\mathrm{H}_{2}\right.$ gas $)$ by photocatalytic decomposition of hydrogen-containing chemicals. Thus highly efficient photo-catalysts are desirable to commercialize the solar hydrogen production research. Perovskite, $\mathrm{ABO}_{3}$ type materials are considered as promising photocatalyst for water splitting under UV light, because of their higher reduction potential and lower oxidation potential. ${ }^{1-4} \mathrm{Cubic}$ perovskite $\mathrm{CaTiO}_{3}$, a large band gap $(3.5 \mathrm{~V})$ material is known to work as photocatalyst only under UV light. ${ }^{4}$ Additionally, it also displays a suitable conduction/valence band positions (as desirable for photocatalytic water

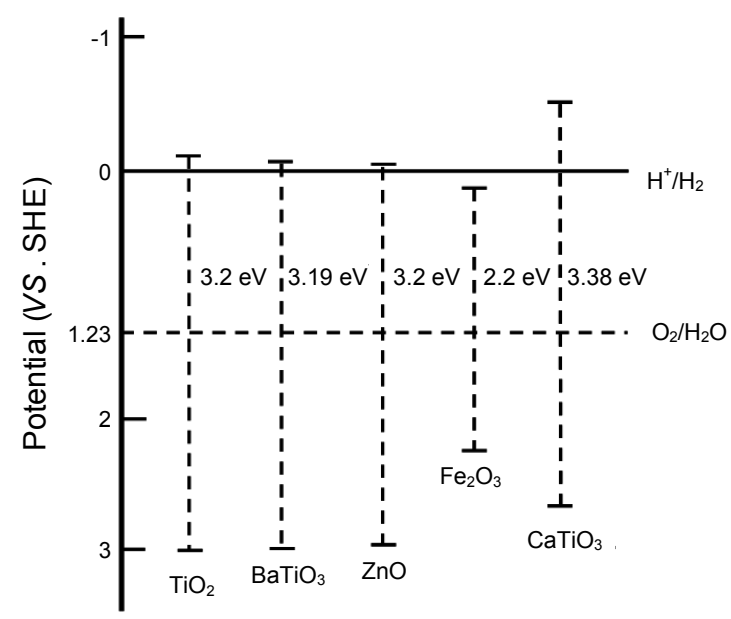

Figure 1. Schematic diagram showing the positions of valence and conduction band edges for different metal oxides in contact with aqueous electrolyte at $\mathrm{pH}=0 . \mathrm{CaTiO}_{3}$ is also included in the diagram to validate its suitability for photocatalyst water splitting application. splitting) as shown in Figure 1. The eco-friendly calcium containing titanate thus becomes an interesting candidate for photocatalytic hydrogen production. However, since the visible light accounts for the largest portion ( $\mathrm{ca} .46 \%$ ) in the solar spectrum, the solar light-driven photocatalysts producing hydrogen from water splitting/aqueous electrolytes is desirable. ${ }^{5-9}$ Hence, development of visible light photocatalysts has become an important topic in the photocatalysis research today. One potential and promising approach to develop new visible active photocatalyst is by modification of the optical properties of UV light active photocatalysts. This can done by substitution of a metal ion in a large band gap lattice, as demonstrated in $\mathrm{Ni}_{\mathrm{x}} \mathrm{In}_{1-\mathrm{x}} \mathrm{TaO}_{4}{ }^{10}$ $\mathrm{La}_{2} \mathrm{Ti}_{2-\mathrm{x}} \mathrm{Cr}_{\mathrm{x}} \mathrm{O}_{7},{ }^{11} \mathrm{TiO}_{2-\mathrm{x}} \mathrm{Cr}_{\mathrm{x}} \mathrm{O}_{2},{ }^{12} \mathrm{SrTi}_{\mathrm{x}} \mathrm{M}_{1-\mathrm{x}} \mathrm{O}_{3}(\mathrm{M}=\mathrm{Ru}, \mathrm{Rh}, \mathrm{Ir}$, $\mathrm{Pt}, \mathrm{Pd}){ }^{13} \mathrm{TiO}_{2-\mathrm{x}} \mathrm{C}_{\mathrm{x}},{ }^{14,15}$ or $\mathrm{Sr}_{2} \mathrm{Nb}_{2} \mathrm{O}_{7-\mathrm{x}} \mathrm{N}_{\mathrm{x}}{ }^{16}$ for cation and anion doping. We have sought cubic perovskite $\mathrm{CaTiO}_{3}$, and doped it with Fe to convert the UV-light active photocatalyst to a visible light active photocatalyst.

In present work, we have controlled the band gap energy of $\mathrm{CaTiO}_{3}$ by substitutional Fe doping in the $\mathrm{CaTiO}_{3}$ host lattice. A simple conventional solid state reaction was used for the doping of $\mathrm{CaTiO}_{3}$. The samples were characterized using UVvis diffuse reflectance spectroscopy (UV-vis DRS) and X-ray diffraction (XRD). This work also describes the study on the photocatalytic activity of hydrogen production from watermethanol mixture under both, UV and visible light irradiation $(\lambda>420 \mathrm{~nm})$

\section{Experimental}

Preparation of Nanocrystalline $\mathrm{CaTi}_{1-\mathbf{x}} \mathrm{Fe}_{\mathbf{x}} \mathrm{O}_{3} \cdot \mathrm{CaTi}_{1-\mathrm{x}} \mathrm{Fe}_{\mathrm{x}} \mathrm{O}_{3}$ $(0 \leq \mathrm{x} \leq 0.4)$ samples were synthesized by the conventional solid state reaction (SSR) method. The $\mathrm{CaTi}_{1-\mathrm{x}} \mathrm{Fe}_{\mathrm{x}} \mathrm{O}_{3}(0 \leq \mathrm{x} \leq 0.4)$ samples were prepared by the stoichiometric variation in $\mathrm{Ti} / \mathrm{Fe}$ 
precursor using during the SSR reaction. Accordingly, the stoichiometric amounts of $\mathrm{CaCO}_{3}\left(99.99 \%\right.$, Aldrich), $\mathrm{TiO}_{2}(99.9 \%$, Aldrich) and $\mathrm{Fe}_{2} \mathrm{O}_{3}(99.99 \%$, Aldrich) were mixed and ground in methanol. The pelletized powders were calcined at $1100{ }^{\circ} \mathrm{C}$ for $5 \mathrm{~h}$ in static furnace $\mathrm{The}^{\mathrm{TiO}}{ }_{2-\mathrm{x}} \mathrm{N}_{\mathrm{x}}$ nanoparticles were also prepared by our previously reported synthesis method, ${ }^{17}$ for the purpose of comparison of photocatalytic activity of various samples. It is needless to say that the oxynitride is well known visible light photocatalyst standard, and several reports are published in past. Thus, the finer details are not described here.

Characterization. $\mathrm{CaTi}_{1-\mathrm{x}} \mathrm{Fe}_{\mathrm{x}} \mathrm{O}_{3}(0 \leq \mathrm{x} \leq 0.4)$ samples were characterized by X-ray Diffractometer (Mac Science Co., M18$\mathrm{XHF}$ ). X-ray diffraction (XRD) results were compared with the Joint Committee Powder Diffraction Standards (JCPDS) data for phase identification. The optical properties of the as-prepared samples were studied by UV-visible diffuse reflectance spectrometer (Shimadzu, UV 2401). The dispersion of Pt deposited on $\mathrm{CaTi}_{0.9} \mathrm{Fe}_{0.1} \mathrm{O}_{3}$ sample was observed by high-resolution transmission electron microscopy (HR-TEM, Philips, CM 200).

Photocatalytic Activity. The rate of photocatalytic hydrogen generation was determined by irradiating the mixture of $0.1 \mathrm{~g}$ catalyst and water-methanol mixed solution (distilled water $70 \mathrm{~mL}$ and methanol $30 \mathrm{~mL}$ ) with UV or visible light source from the arc-discharge bulb. Especially a $420 \mathrm{~nm}$ band pass optical filter was used for shining the visible light. The amount of $\mathrm{H}_{2}$ evolved was analyzed by gas chromatography (GC) equipped with a thermal conductivity detector (molecular sieve 5- $\AA$ column and Ar carrier). Pt loaded photocatalysts were prepared by known standard method of in-situ photodeposition ${ }^{18}$ method. For this the photocatalyst powder was added to an aqueous methanol solution containing a required amount $(0.1 \sim$ $1.0 \mathrm{wt} \%$ ) of $\mathrm{H}_{2} \mathrm{PtCl}_{6}$. The solution was illuminated for $2 \mathrm{~h}$ under visible light $(\lambda \sim 420 \mathrm{~nm})$, filtered and then dried in a static oven at $80 \sim 100{ }^{\circ} \mathrm{C}$.

\section{Results and Discussion}

Figure 2 shows the XRD patterns of $\mathrm{CaTi}_{1-\mathrm{x}} \mathrm{Fe}_{\mathrm{x}} \mathrm{O}_{3}(0 \leq \mathrm{x} \leq$ 0.4) samples prepared by sintering the ground mixture of $\mathrm{CaCO}_{3}$, $\mathrm{TiO}_{2}$ and $\mathrm{Fe}_{2} \mathrm{O}_{3}$ at $1100{ }^{\circ} \mathrm{C}$ for $5 \mathrm{~h}$ in air. Thus obtained sample exhibited a pure orthorhombic phase $\mathrm{CaTiO}_{3}$ structure with the lattice parameters of $a=5.37, b=7.64$, and $c=5.44 \AA$. The increase in the iron $(x>0.1)$ concentration showed that there was a gradual shift in $\mathrm{x}$-ray diffraction peak (121) towards larger angle. This gradual shift of the main (121) peak towards larger diffraction angle is correlated with the increment in the lattice constants. It is known that the difference in the ionic radii of $\mathrm{Ti}^{4+}(0.61 \AA)$ and $\mathrm{Fe}^{3+}(0.62) \AA$ ions is too small to induce any unit cell deformation, thus validating the peak shift to lattice expansion. Further, no other impurity phase was observed except for the sample with the highest iron concentration. The intermediate iron concentration samples with $0.15 \leq \mathrm{x} \leq 0.4$ exhibited a mixed phase containing $\mathrm{CaTiO}_{3}$ and unknown phase as shown in Figure $2(\mathrm{~d}) \sim(\mathrm{g})$. This indicates that there exists a maximum limit to the Fe dopant concentration that can be substituted into the Ti site of $\mathrm{CaTiO}_{3}$ crystal structure without the deformation of the original structure.

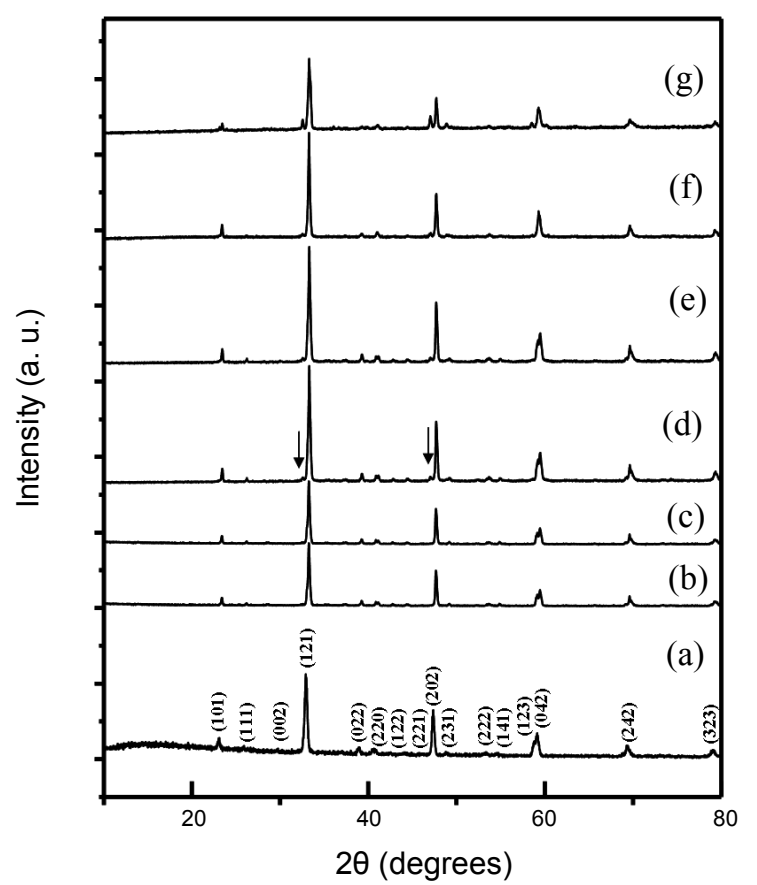

Figure 2. X-ray diffraction spectra for respective samples of $\mathrm{CaTi}_{1-\mathrm{x}}{ }^{-}$ $\mathrm{Fe}_{\mathrm{x}} \mathrm{O}_{3}$ (for $0 \leq \mathrm{x} \leq 0.4$ ) photocatalysts viz. for (a) $\mathrm{x}=0$, (b) 0.05 ; (c) 0.1 ; (d) 0.15 ; (e) 0.2 ; (f) 0.3 ; and (g) 0.4 .

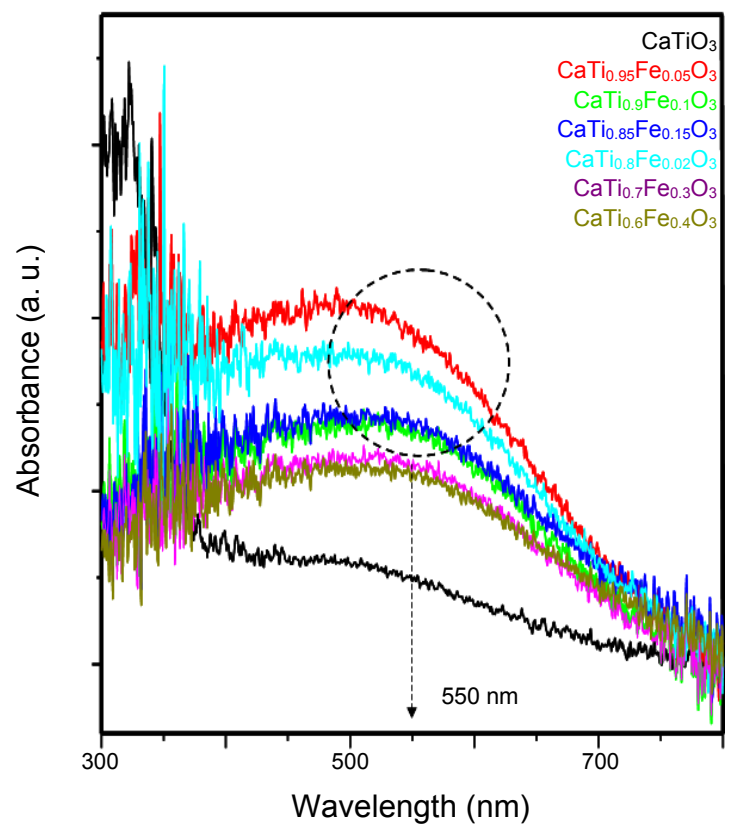

Figure 3. UV-vis diffuse reflectance spectra of $\mathrm{CaTi}_{1-\mathrm{x}} \mathrm{Fe}_{\mathrm{x}} \mathrm{O}_{3}$ photocatalysts for viz. for (a) $\mathrm{x}=0$, (b) 0.05 ; (c) 0.1 ; (d) 0.15 ; (e) 0.2 ; (f) 0.3 ; and (g) 0.4 .

The optical properties of iron doped $\mathrm{CaTiO}_{3}$ samples were investigated by UV-vis diffuse reflectance (UV-DR) spectroscopy. Figure 3 shows the UV-visible diffuse reflectance spectra of $\mathrm{CaTi}_{1-\mathrm{x}} \mathrm{Fe}_{\mathrm{x}} \mathrm{O}_{3}$ samples $(0 \leq \mathrm{x} \leq 0.4)$. In case of undoped $\mathrm{CaTiO}_{3}$ sample, absorption edge appeared near $388 \mathrm{~nm}$ corresponding to $3.2 \mathrm{eV}$, consistent with the literature value. ${ }^{4}$ However, the absorption spectra of $\mathrm{Fe}$ doped $\mathrm{CaTiO}_{3}$ samples drama- 
tically changed depending on the iron concentration and exhibited a new absorption shoulder in the visible light region. In general, the absorption edge of $\mathrm{CaTiO}_{3}$ around $388 \mathrm{~nm}$ is ascribed to the band transition from O $2 p$ to Ti $3 d$. The doping of iron in $\mathrm{CaTiO}_{3}$, induce an appearance of a shoulder, this absorption is due to the electronic transition from $\mathrm{Fe} e_{\mathrm{g}}$ to $\mathrm{Fe} 4 s$. In this case, the interband may exist between the conduction and valence band of $\mathrm{CaTiO}_{3}$. Interestingly, due to appearance of the absorbance feature in visible range we explored the visible light photocatalytic properties for these doped samples. We investigated their photocatalytic hydrogen producing capacity from methanol-water solution using under both, UV and visible light irradiation conditions.

Further, we investigated the dependence of the photocatalytic activity on the amount of $\mathrm{Pt}$ loading on $\mathrm{CaTi}_{0.9} \mathrm{Fe}_{0.1} \mathrm{O}_{3}$ sample under visible light irradiation $(\lambda \geq 420 \mathrm{~nm})$. The photocatalytic activity showed a maximum activity at $0.25 \mathrm{Pt}$ wt $\%$ and then gradually decreased with further increase of the amount of $\mathrm{Pt}$ loading as shown in Figure 4. Thus, it indicates that an optimum level of Pt loading on $\mathrm{CaTi}_{0.9} \mathrm{Fe}_{0.1} \mathrm{O}_{3}$ is necessary for an efficient hydrogen production. It is worth mentioning here that Pt-loading

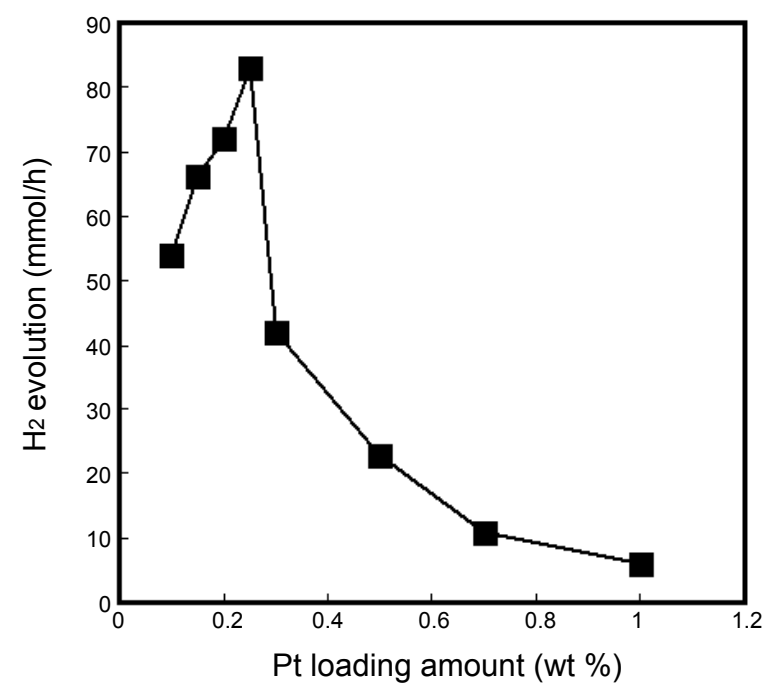

Figure 4. The effect of Pt-loading (in $\mathrm{CaTi}_{0.9} \mathrm{Fe}_{0.1} \mathrm{O}_{3}$ ) on the photocatalytic hydrogen production, under visible light irradiation $(\lambda \geq 420 \mathrm{~nm})$. plays vital role as co-catalyst thereby favoring the electron-hole charge separation during the photocatalytic reaction. The concentration dependence high efficiency can be correlated to the optimum Pt-concentration. This indicates that low Pt is not sufficient to take part in the photocatalytic reaction, whereas at high Pt-concentration the metallic species act as electron trapping centers thus reducing the efficiency of photocatalytic reduction.

Table 1 shows the results of $\mathrm{H}_{2}$ evolution estimated from photocatalytic experiment, as well as the bandgap energy of the samples estimated from the respective DRS spectra. All the Pt-loaded samples showed the photocatalytic activity for $\mathrm{H}_{2}$ production from methanol-water solution under UV light irradiation $(\lambda \geq 210 \mathrm{~nm})$. Among all samples the undoped $\mathrm{CaTiO}_{3}$ showed the maximum photocatalytic activity under UV light irradiation. The activity decreased with the increase in the iron concentration as seen in Table 1. The same samples behaved differently under visible light irradiation. Interestingly under visible light irradiation, $\mathrm{CaTi}_{1-\mathrm{x}} \mathrm{Fe}_{\mathrm{x}} \mathrm{O}_{3}$ samples with $\mathrm{x}=0.05$, 0.1 only showed significant $\mathrm{H}_{2}$ production as high as 38,83 $\mathrm{mmol} /$ gcat $\cdot \mathrm{hr}$, respectively. But, $\mathrm{TiO}_{2-\mathrm{x}} \mathrm{N}_{\mathrm{x}}$, undoped and other doped $\mathrm{CaTiO}_{3}(\mathrm{x}=0.15 \leq \mathrm{x} \leq 0.4)$ samples showed only a trace amount or no $\mathrm{H}_{2}$ production under visible light irradiation. $\mathrm{CaTi}_{0.9} \mathrm{Fe}_{0.1} \mathrm{O}_{3}$ sample showed the highest photocatalytic activity for hydrogen production under visible light irradiation $(\lambda \geq$ $420 \mathrm{~nm}$ ). This indicates that the $\mathrm{CaTi}_{0.9} \mathrm{Fe}_{0.1} \mathrm{O}_{3}$ seems to have optimum $\mathrm{Fe}$ concentration for responsible for yielding a relatively high photocatalytic activity. This behavior can be mainly due to two factors, (1) the $\mathrm{CaTi}_{0.9} \mathrm{Fe}_{0.1} \mathrm{O}_{3}$ sample shows a maximum visible light absorption as observed in Figure 3.; (2) In contrast to the $\mathrm{CaTi}_{0.9} \mathrm{Fe}_{0.1} \mathrm{O}_{3}$, the other $\mathrm{Fe}$ doping concentrations possibly lead to an impurity phase and/or unfavorable defect states those are responsible for unnecessary recombination loss.

XPS measurements were carried out to analyze the oxidation state of $\mathrm{Fe}$-ion in $\mathrm{CaTi}_{0.9} \mathrm{Fe}_{0.1} \mathrm{O}_{4}$ photocatalyst. Figure 5(a) shows the XPS survey spectrum of $\mathrm{CaTi}_{0.9} \mathrm{Fe}_{0.1} \mathrm{O}_{4}$ sample, indicating the existence of $\mathrm{Ca}, \mathrm{Ti}, \mathrm{O}, \mathrm{C}$ and $\mathrm{Fe}$ elements as confirmed by the photoelectron peaks appearing at binding energies of 347 $\left(\mathrm{Ca} 2 \mathrm{p}_{3 / 2}\right), 459$ (Ti 2 $\left.\mathrm{p}_{3 / 2}\right), 531$ (O 1s) and $285 \mathrm{eV}$ (C 1s) and a weak photoelectron peak at $711 \mathrm{eV}\left(\mathrm{Fe} 2 \mathrm{p}_{3 / 2}\right)$. The Figure 5(b) displays the core level spectra of the $\mathrm{Fe} 2 \mathrm{p}_{3 / 2}$ revealing that the peak at $711 \mathrm{eV}$ is symmetrical and thus Fe-ion can be ascribed

Table 1. Photocatalytic $\mathrm{H}_{2}$ production from methanol-water solution over $0.25 \mathrm{wt} \% \mathrm{Pt} / \mathrm{CaTi}_{1-\mathrm{x}} \mathrm{Fe}_{\mathrm{x}} \mathrm{O}_{3}(0.0 \leq \mathrm{x} \leq 0.4)$ and $\mathrm{TiO}_{2-\mathrm{x}} \mathrm{N}_{\mathrm{x}}$ samples

\begin{tabular}{|c|c|c|c|c|}
\hline \multirow[b]{2}{*}{ Catalyst } & \multicolumn{2}{|c|}{ Energy Bandgap } & \multicolumn{2}{|c|}{$\mathrm{H}_{2}$ evolution $(\mathrm{mmol} / \mathrm{g} \cdot \mathrm{cat})$} \\
\hline & $\mathrm{Eg}(\mathrm{eV})-1$ & $\mathrm{Eg}(\mathrm{eV})-2$ & $\begin{array}{l}\text { UV light irradiation } \\
\qquad(\lambda \geq 210 \mathrm{~nm})\end{array}$ & $\begin{array}{l}\text { Visible light irradiation } \\
\qquad(\lambda \geq 420 \mathrm{~nm})\end{array}$ \\
\hline $\mathrm{Pt} / \mathrm{CaTiO}_{3}$ & 3.38 & - & 171 & 0 \\
\hline $\mathrm{Pt} / \mathrm{CaTi}_{0.95} \mathrm{Fe}_{0.05} \mathrm{O}_{3}$ & 3.38 & 2.25 & 131 & 38 \\
\hline $\mathrm{Pt} / \mathrm{CaTi}_{0.90} \mathrm{Fe}_{0.10} \mathrm{O}_{3}$ & 3.38 & 2.25 & 127 & 83 \\
\hline $\mathrm{Pt} / \mathrm{CaTi}_{0.85} \mathrm{Fe}_{0.15} \mathrm{O}_{3}$ & 3.38 & 2.25 & 84 & Trace \\
\hline $\mathrm{Pt} / \mathrm{CaTi}_{0.80} \mathrm{Fe}_{0.20} \mathrm{O}_{3}$ & 3.38 & 2.25 & 26 & 0 \\
\hline $\mathrm{Pt} / \mathrm{CaTi}_{0.70} \mathrm{Fe}_{0.30} \mathrm{O}_{3}$ & 3.38 & 2.25 & 11 & 0 \\
\hline $\mathrm{Pt} / \mathrm{CaTi}_{0.60} \mathrm{Fe}_{0.40} \mathrm{O}_{3}$ & 3.38 & 2.25 & 8 & 0 \\
\hline $\mathrm{Pt} / \mathrm{TiO}_{2-\mathrm{x}} \mathrm{N}_{\mathrm{x}}$ & 3.2 & 2.73 & 8 & Trace \\
\hline
\end{tabular}


(A)

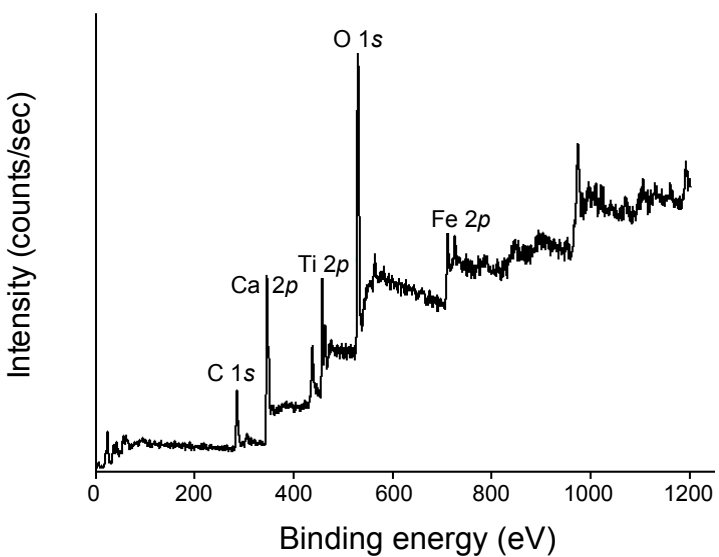

(B)

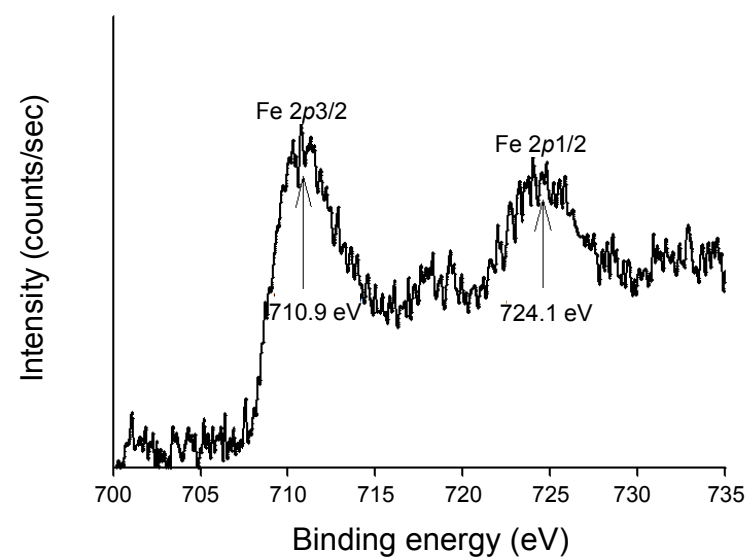

Figure 5. (A) X-ray photoelectron spectroscopy survey spectrum of $\mathrm{CaTi}_{0.9} \mathrm{Fe}_{0.1} \mathrm{O}_{3}$ sample; (B) The XPS core-level spectra of $\mathrm{Fe} 3 p$ for $\mathrm{CaTi}_{0.9} \mathrm{Fe}_{0.1} \mathrm{O}_{3}$ sample, displaying the components of $\mathrm{Fe}-3 p$ doublet.

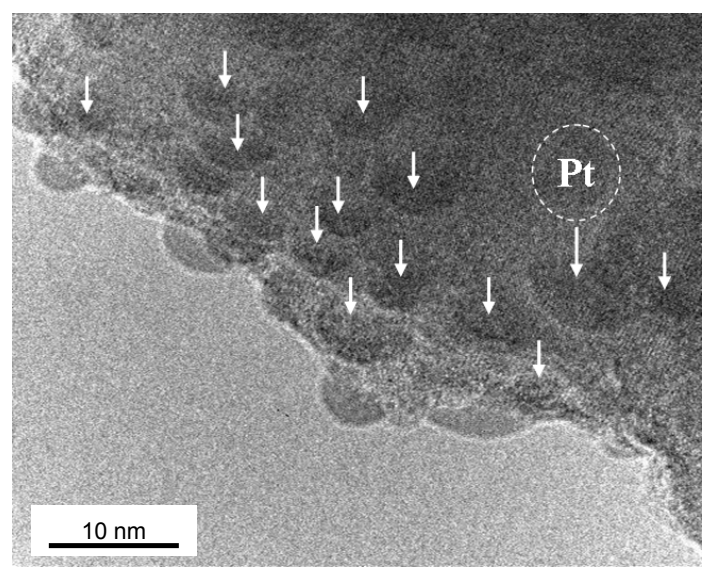

Figure 6. HR-TEM image of 0.25 wt \% Pt-loaded $\mathrm{CaTi}_{0.9} \mathrm{Fe}_{0.1} \mathrm{O}_{3}$ sample. The loading of $0.25 \mathrm{Pt}$ wt $\%$ over $\mathrm{CaTi}_{0.9} \mathrm{Fe}_{0.1} \mathrm{O}_{3}$ surface was done by photodeposition method (See text).

to the trivalent oxidation state $\left(\mathrm{Fe}^{3+}\right)$.

In Figure 6, HR-TEM image shows the uniformly dispersed platinum nanoparticles over the $\mathrm{CaTi}_{0.9} \mathrm{Fe}_{0.1} \mathrm{O}_{3}$ sample. Specifically, the $0.25 \mathrm{wt} \% \mathrm{Pt}$ loaded on $\mathrm{CaTi}_{0.9} \mathrm{Fe}_{0.1} \mathrm{O}_{3}$ sample shows best dispersion as shown in Figure 6. We think that this is one
(A)

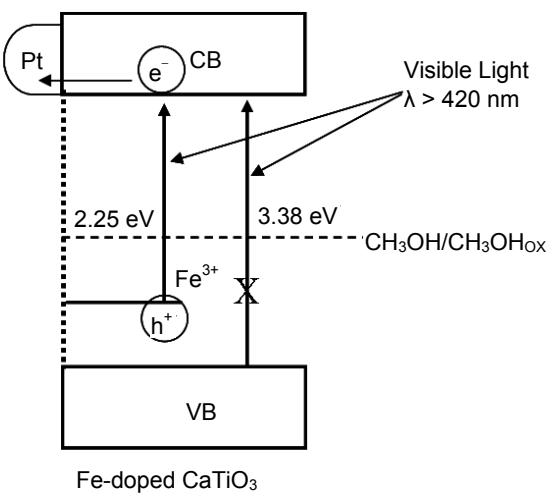

(B)

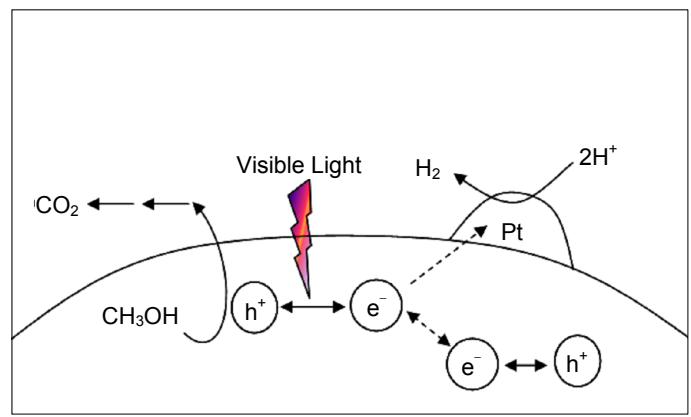

Figure 7. Schematic of (A) proposed band structure of $\mathrm{CaTi}_{1-\mathrm{x}} \mathrm{Fe}_{\mathrm{x}} \mathrm{O}_{3}$ system; displaying (B) the mechanism for photocatalytic hydrogen production from methanol-water solution.

of the important factors responsible to yield the best photocatalytic activity over $0.25 \mathrm{wt} \% \mathrm{Pt}_{-} \mathrm{CaTi}_{1-\mathrm{x}} \mathrm{Fe}_{\mathrm{x}} \mathrm{O}_{3}(0 \leq \mathrm{x} \leq 0.4)$ sample.

Figure 7 show the schematic of $\mathrm{CaTi}_{1-\mathrm{x}} \mathrm{Fe}_{\mathrm{x}} \mathrm{O}_{3}$ band structure that proposes the mechanism of photocatalytic hydrogen production from methanol-water solution over it. As shown the $\mathrm{Fe}$ (III) doping forms an interband between the conduction and valence band of undoped $\mathrm{CaTiO}_{3}$, and thus $\mathrm{Fe}$ doped $\mathrm{CaTiO}_{3}$ produced $\mathrm{H}_{2}$ photocatalytically in the presence of aqueous methanol-water solution under visible light. Thus, in the case of $\mathrm{Pt} / \mathrm{Fe}$ doped $\mathrm{CaTiO}_{3}$, an electron excited to the conduction band has sufficient reduction potential to reduce $\mathrm{H}^{+}$ion, similarly the holes in the valence band has lower oxidation potential for the oxidation of $\mathrm{CH}_{3} \mathrm{OH}$ to $\mathrm{CO}_{2}$. Accordingly, $\mathrm{Fe}$ doped $\mathrm{CaTiO}_{3}$ can be used for the photo-reduction as well as for photo-oxidation of various discussed components.

\section{Conclusions}

$\mathrm{CaTi}_{1-\mathrm{x}} \mathrm{Fe}_{\mathrm{x}} \mathrm{O}_{3}$ photocatalysts were successfully synthesized by solid state reaction method. The variation of $\mathrm{x}$ in $\mathrm{CaTi}_{1-\mathrm{x}} \mathrm{Fe}_{\mathrm{x}} \mathrm{O}_{3}$ $(0.05 \leq \mathrm{x} \leq 0.4)$ samples allowed us to modify the optical property by yielding a new band in the visible light range. $\mathrm{CaTi}_{1-\mathrm{x}} \mathrm{Fe}_{\mathrm{x}} \mathrm{O}_{3}(0.05 \leq \mathrm{x} \leq 0.1)$ samples with low doping level were synthesized without impurity phase, and showed the significant photocatalytic activity under visible light. Higher Fe dopant concentration led to the formation of unknown impurity phase. Photocatalytic activity of $0.25 \mathrm{wt} \% \mathrm{Pt} / \mathrm{CaTi}_{0.9} \mathrm{Fe}_{0.1} \mathrm{O}_{3}$ sample is much higher than activity of $1.0 \mathrm{wt} \% \mathrm{Pt} / \mathrm{CaTi}_{0 .} \mathrm{Fe}_{0.1} \mathrm{O}_{3}$ and reference visible light photocatayst $\left(\mathrm{TiO}_{2-\mathrm{x}} \mathrm{N}_{\mathrm{x}}\right)$ for $\mathrm{H}_{2}$ produc- 
tion under UV and visible light. Fe doping play an important role in inducing the visible light absorption in $\mathrm{CaTiO}_{3}$, and showing the photocatalytic activity for hydrogen production in the system of $\mathrm{CaTiO}_{3}$ under visible light irradiation.

Acknowledgments. This work has been supported by KBSI grant (T30320), Hydrogen Energy R\&D Center, Korea.

\section{Reference}

1. Yin, J.; Zou, Z.; Ye, J. J. Phys. Chem. B 2003, 107, 61.

2. Hideki, H.; Kiyotaka, K.; Kudo, A. J. Am. Chem. Soc. 2003, 125, 3082 .

3. Domen, K.; Kudo, A.; Onishi, T.; Kosugi, N.; Kuroda, H. J. Phys. Chem. 1983, 90, 292.

4. Mizoguchi, H.; Ueda, K.; Orita, M.; Moon, S. C.; Kajihara, K.; Hirano, M.; Hosono, H. Mater. Res. Bull. 2002, 37, 2401.

5. Kudo, A. Catal. Survey from Asia 2003, 7, 31.

6. Domen, K.; Hara, M.; Kondo, J. N.; Takata, T.; Kudo, A.; Kobayashi, H.; Inoue, Y. Korean J. Chem. Eng. 2001, 18, 862.
7. Kim, H. G.; Borse, P. H.; Choi, W.; Lee, J. S. Angew. Chem. Int. Ed. 2005, 44, 4585.

8. Kato, H.; Asakura, K.; Kudo, A. J. Am. Chem. Soc. 2003, 125, 3082.

9. Kim, H. G.; Hwang, D. W.; Lee, J. S. J. Am. Chem. Soc. 2004, $126,8912$.

10. Zou, Z.; Ye, J.; Sayama, K.; Arakawa, H. Nature 2002, 424, 625.

11. Hwang, D. W.; Kim, H. G.; Lee, J. S.; Kim, J.; Li, W.; Oh, S. H. J. Phys. Chem. B 2005, 109, 2093.

12. Bae, S. W.; Borse, P. H.; Hong, S. J.; Jang, J. S.; Lee, J. S.; Jeong, E. D.; Hong, T. E.; Yoon, J. H.; Jin, J. S.; Kim, H. G. J. Korean Phys. Soc. 2007, 51, S22.

13. Bae, S. W.; Borse, P. H.; Lee, J. S. Appl. Phys. Lett. 2008, 92 , 104107/1

14. Khan, S. U. M.; Al-Shahry, M.; Ingler. Jr., W. B. Science 2002 , 297, 2243.

15. Mitoraj, D.; Kisch, H. Angew. Chem. Int. Ed. 2008, 47, 9975.

16. Ji, S. M.; Borse, P. H.; Kim, H. G.; Hwang, D. W.; Jang, J. S.; Bae, S. W.; Lee, J. S. Phys. Chem. Chem. Phys. 2005, 7, 1315.

17. Jang, J. S.; Kim, H. G.; Ji, S. M.; Bae, S. W.; Jung, J. H.; Shon, B. H.; Lee, J. S. J. Solid State Chem. 2006, 179, 1064

18. Reber, J-F.; Rusek, M. J. Phys. Chem. 1986, 90, 824. 